\title{
In the absence of values and ideologies, Party-switching in Nigeria is inevitable.
}

\author{
Emmanuel Mogaji \\ University of Greenwich, London, UK \\ e.o.mogaji@greenwich.ac.uk
}

\begin{abstract}
This paper aims to explore the absence of values and ideologies within the political parties and how it contributes towards party switching, using the Nigerian political scene as a focus point. The personal values and ideologies of individual politicians was questioned as well. This paper further postulated that the neither the Nigerian politicians nor the political parties have values and ideologies they stand for. Not surprising there cannot be any alignment and politicians able to switch their party at will. They are not principled to stand for something that does not exists. Moving on beyond the 2019 election in Nigeria, the paper offers practical insights into brand identity development for political parties, especially the new ones.
\end{abstract}

Keywords: Nigeria, APC, PDP, Party Switching, Brand Values, ideologies.

\section{Introduction}

Party switching provides unique insight into party systems and it is common in many countries (Desposato, 2006) and Nigeria is not an exemption being the most populated black nation in the world. Politicians and elected public office holders in Nigeria are known to decamp from the party on whose platform they got elected to another. Often, they give the notion of irreconcilable differences in the party for their reason for decamping, however selfish political gains have often been anecdotally identified as their primary reason for this decamping. This aligns with earlier findings by Desposato (2006) that politicians use parties to advance their political careers. While not minding the part switching, this paper explores the inherent values and brand ideologies of a typical Nigerian politician and how it at all it aligns with the ideologies of the political party.

Since these politicians were elected on the platform of a party at the start of their term, they must have believed in the ideologies and willing to align themselves with it, but the question is, what could have happened to their values as they decamp? This paper postulates that the neither the Nigerian politicians nor the political parties have values and ideologies they stand for. Not surprising there cannot be any alignment and politicians able to switch their party at will. They are not principled to stand for something that does not exists. Moving on beyond the 2019 election in Nigeria, the paper further offers practical insights into brand identity development for political parties, especially the new ones. 


\section{Situation on ground}

All Progressives Congress (APC) is the ruling political party in Nigeria, and they have had the majority in the Senate, however, things have not been rosy as expected. Recently, there has been mass decampment. Fifteen senators belonging APC defected to the opposition People's Democratic Party (PDP) (Olasupo, 2018), Likewise, after weeks of speculation, the Senate President - Bukola Saraki, the number three man in the country announced on his verified Twitter handle that he is leaving APC (Jimoh \& Ebiri, 2018) and to crown it all up, the Publicity Secretary of the APC - Bolaji Abdullahi also dumped the party (Erezi \& Olasupo, 2018)

These are all public office holders that were elected on the platform of the APC, the electorate voted for them because they assume they align their values with APC, but the question is why the politicians have decided to leave a place where they were proud to share its platform just a few years ago? No doubt people can leave a party and move to another, but the main crux of the matter presented therein is the ideologies and values of the political party they belong to.

For the Publicity Secretary of a party to decamp and leave immediately shows that there is no belief in that values or there is no value to believe in in the first place. This is not a secretary stepping down from his position but leaving the party. Before a public secretary is selected, he/she must have been a member of the party, believed in their values and be willing to stay on the rooftop to shout it out, but if suddenly the publicity secretary decided to switch allegiances, it shows there is nothing to stand for in the party.

It is important to note that some of these public holders that decamped where formerly in People's Democratic Party (PDP). In Saraki's speech after dumping APC for PDP, he declared: 'For me, I leave all that behind me. Today, I start as I return to the party where I began my political journey'. The question is if they left PDP to APC to actualise their political aspiration on a party they believed was different, so why are they all returning? Saraki went on to say 'When we left the PDP to join the then-nascent coalition of APC in 2014, we left in a quest for justice, equity and inclusion; the fundamental principles on which the PDP was originally built but which it had deviated from. We were attracted to the APC by its promise of change. We fought hard along with others and defeated the PDP.' (Odunsi, 2018).

Speaker of the House of Representative, Mr Yakubu Dogara, elected on the APC platform also defected to PDP and picked the nomination and expression of interest form to return to the House in 2019. The need to defect to be assured of a return to the house is questionable, perhaps there is no assurance that APC will make him the flagbearer. This confirms Aldrich \& Bianc (1992)'s findings that the competition for a party's nomination can prompt party switches, and in the context of declining party strength.

Two points need to be addressed in this context. Firstly, the values of a Nigerian politician and the values of the Nigerian political party. If a politician is mindful of 
his/her values and ideologies, it will be challenging to switch allegiance to another party that doesn't have the same values. Moreover, on that note, it is postulated that politicians or political parties in Nigeria do not have values that highlight their integrity. No doubt there could be exemptions as these postulations have not been empirically validated, but there are still existing concerns about the integrity of Nigerian politicians and inherent values, ideologies and philosophy of the political parties.

\section{Way Forward}

Moving on to 2019 and beyond, it is crucial for APC to consider how to position itself as a party to remain relevant in the political landscape of Nigeria. As active and office holding members are leaving, what are the plans to remain viable? Needham (2006) noted that political parties need to use marketing not only to win an election but also to minimise post-purchase dissonance and encourage brand loyalty. Parties need to engage and communicate with their members not just for winning the election but for long-term brand loyalty.

Mogaji, (2013) wrote about the brand identity of APC when they just formed the party in 2013; but at this stage, it is essential to consider a move beyond their logo and brand identity but reinforcing the values of the party. The party has a Broom in their logo; they use the Broom as a physical symbol of identity during primaries, does that, therefore, mean they are sweeping away corruption, or they are sweeping the government coffers? What does the APC broom stand for? What does APC stand for as a political party? This party need to highlight what they stand against; how are they different from PDP the opposition party or the other political parties in the country? What makes APC stands out as a party compared to others? It is crucial to note this because if a party knows what it stands for, any member they are accepting will be willing to align with those values. A functional and accessible website will be the first place to communicate this.

The internal conflict within the party is also acknowledged, however in the wake of this decampment; it is crucial for the party to make conscious effort to put their house in order and make an effort to communicate their values, provided they have one, and hopefully the electorate and other stakeholders can buy into this. Creating this identity requires a professional and tactical approach, which needs to be communicated right from the presidency to those in the local government, those who still choose to be part of the APC should know what it stands for and be able to abide by it.

Scammell (2007) argued that branding is the new form of political marketing, this moves just beyond the popular term for image and identity but creating and standing by values and principles that distinguish the political party from others. Political parties, especially in Africa needs to identify these identities and effectively communicate them to build a successful brand because knowing what the brand stands is crucial (Aaker, 1996). With other parties coming to the political scene of Nigeria, it is important they have their 
ideologies and build their identities and values around it. No doubt, this will take much effort, a long-term plan needs to be adopted. As brand faces aggressive competition in the political scene, brand personality and reputation of a party can help distinguish from competing offerings (Ghodeswar, 2008).

For political parties in Nigeria, their identity needs to resonate with the electorates, differentiate them from competitors, and represent what the organisation can and will do over time (Aaker \& Joachimsthaler, 2000). Moving beyond having a Squirrel (Allied Congress Party of Nigeria), Fish (Hope Democratic Party) or Bee (National Rescue Movement) as a logo; but to be sure they stand for something. It is crucial that these identities align well with the values they hold and anyone joining has a member will know what they stand for. Having a presence online in the form of websites and social media which aid engagement cannot be overemphasised.

Studies have shown that political party branding is moving beyond just being ideologically driven but towards being more marketing oriented, highlighting that is becoming part of everyday consumer behaviour (Reeves et al., 2006), however, it appeared there are challenges with politics in Africa. The ideologies are not yet well embedded before moving towards creating and integrating their brand values and identities. Party members do not believe in ideologies that do not exist.

This might be too much to ask a typical African politician, but it is essential to have personal values which they standby. The highlights their integrity and ability to remain principled even though things do not go their way (within their party). It is not surprising to see Nigerian politician leave a party for another when they cannot get the nomination ticket. This indicates how strong their value and ideologies are. The internal problem within the party to necessitate the need to decamp cannot be ignored, but it is essential for politicians to make knowns their values and stand by it.

\section{Conclusion}

There is lack of research and empirical information about political branding and marketing in Africa, and this article serves as an effort in a little way to add to this knowledge and stir up further discussion around this topic. Two key issues have been identified - values of a typical Nigerian politician and the values of a political party. It is postulated that individual values and belief may change as they move towards actualising their political aspirations, but the values of a political party should not change.

It is expected that political parties, especially in Nigeria and not just APC needs to identify their values, belief and ideologies - which should be communicated effectively. New members might want to join, but they should be aware of the inherent values and be able to abide by it. Some may argue that marketing a political party is not a pressing need for Africans, but this feeds into party members who switch allegiance without 
feeling the need to abide by values of their party and serving the needs of those who elected them.

This has been taken in the context of Africa, being the most populated black nation in the world, it would not be surprising if there is evidence of such decamping in other African countries. Further research is suggested to explore brand values and identities of political parties in African and perhaps a typology of decampment within the Nigeria pollical scene.

\section{References}

Aaker, D. A., 1996. Building Strong Brands. New York, NY: The Free Press.

Aaker, D. A. \& Joachimsthaler, E., 2000. The brand relationship spectrum: The key to the brand architecture challenge. California Management Review, 42(4), pp. 8-23.

Aldrich, J. H., \& Bianco, W. T. (1992). A game-theoretic model of party affiliation of candidates and office holders. Mathematical and Computer Modelling, 16(8-9), 103-116.

Desposato, S. W. (2006). Parties for rent? Ambition, ideology, and party switching in Brazil's chamber of deputies. American Journal of Political Science, 50(1), 62-80.

Erezi, D. \& Olasupo, A., 2018. APC spokesperson Bolaji Abdullahi finally dumps party. [Online] Available at: https://guardian.ng/news/apc-spokesman-dumps-party/[Accessed 18 2018].

Ghodeswar, B. M., 2008. Building brand identity in competitive markets: a conceptual model. Journal of Product \& Brand Management, 17(1), pp. 4-12.

Jimoh, A. M. \& Ebiri, K., 2018. Saraki, Kwara governor dump APC, join PDP. [Online] Available at: https://guardian.ng/news/saraki-kwara-governor-dump-apc-join-pdp/[Accessed 18 2018].

Mogaji, E., 2013. Political Party Branding: The Beginning for APC in Nigeria. The Questbury Brand Series, 1(2), pp. 1-3.

Needham, C., 2006. Brands and political loyalty. Journal of Brand Management, 13(3), pp. 178-187.

Odunsi, W., 2018. Saraki's speech after dumping APC for PDP [Full Text]. [Online] Available at: http://dailypost.ng/2018/07/31/sarakis-speech-dumping-apc-pdp-full-text/[Accessed 18 2018].

Olasupo, A., 2018. 15 senators dump APC for PDP. [Online]Available at:

https://guardian.ng/news/15-senators-dump-apc-for-pdp/[Accessed 018 2018].

Reeves, P., de Chernatony, L. \& Carrigan, M., 2006. Building a political brand: Ideology or voter-driven strategy. Journal of Brand Management, 13(6), pp. 418-428.

Scammell, M., 2007. Political brands and consumer citizens: The rebranding of Tony Blair. The Annals of the American Academy of Political and Social Science, 611(1), pp. 176-192. 